\title{
Prostaglandin E2 induces ovulation in prepubertal mice
}

\section{Prostaglandina E2 induz ovulação em camundongos pré-púberes}

\author{
Jéssica de Souza Andrade ${ }^{1}$; Juliana Pavan Zuliani² ${ }^{2}$ Jaswant $_{\text {Singh }}^{3}$; Sulamita da Silva Setúbal²; \\ Renata Reis da Silva'; Augusto Schneider ${ }^{5}$, Luiz Francisco Machado Pfeifer ${ }^{4}$ (I) \\ ${ }^{1}$ Rede Bionorte, Programa de Pós-graduação em Biodiversidade e Biotecnologia, Porto Velho - RO, Brazil \\ ${ }^{2}$ Fundação Oswaldo Cruz de Rondônia, Laboratório de Imunologia Aplicada à Saúde, Porto Velho - RO, Brazil \\ ${ }^{3}$ University of Saskatchewan, Veterinary Biomedical Sciences, Saskatoon - SK, Canada \\ ${ }^{4}$ Empresa Brasileira de Pesquisa Agropecuária, Porto Velho - RO, Brazil \\ ${ }^{5}$ Universidade Federal de Pelotas, Pelotas - RS, Brazil
}

\begin{abstract}
The objective of this study was to determine the ability of prostaglandin $\mathrm{E}_{2}\left(\mathrm{PGE}_{2}\right)$ to induce ovulation and expression of $\mathrm{PGE}_{2}$ receptor (EP2 and EP4) and COX genes (COX-1 and COX-2) in the ovary and pituitary of prepubertal mice. The positive control consisted of the application of $5 \mu \mathrm{g}$ of gonadotropin-releasing hormone $(\mathrm{GnRH}, \mathrm{n}=29)$; the negative control applied $0.5 \mathrm{~mL}$ of phosphate buffered saline (PBS, $\mathrm{n}=31$ ); the treatment tested the application of $250 \mu \mathrm{g}$ of PGE2 $(n=29)$, making a total of 89 prepubertal mice $(B A L B / c)$. Mice were euthanized 14 to $15 \mathrm{~h}$ after treatments to detect ovulation and tissue collection. A Chi-square test was used to compare the proportion of animals ovulating. Gene expressions and number of ovulation were analyzed by one-way ANOVA and Tukey's test was used to compare means among groups. A greater proportion of mice $(\mathrm{P}<0.001)$ ovulated after receiving $\mathrm{GnRH}(89.7 \%, 26 / 29)$ compared to $\mathrm{PGE}_{2}$ group $(58.6 \%, 17 / 29)$. However, the proportion was higher compared to those treated with PBS (0\%, 0/31). Ep2 gene expression in the pituitary was $>$ two-fold higher $(\mathrm{P}<0.05)$ in the $\mathrm{PGE}_{2}$ group compared to the $\mathrm{PBS}$ and $\mathrm{GnRH}$ groups. Further, $\mathrm{PGE}_{2}$ stimulated Cox1 (2.7 fold, $\left.\mathrm{P}<0.05\right)$ while $\mathrm{GnRH}$ stimulated Cox2 expression $(6.5$ fold, $\mathrm{P}<0.05)$ in the pituitary when compared to the PBS group. In conclusion, our results support the hypothesis that $\mathrm{PGE}_{2}$ can induce ovulation in prepubertal mice with a concomitant increase in Ep2 and Cox1 gene expression in the pituitary gland.
\end{abstract}

Keywords: Ovulation. Prostaglandin. Receptor. Puberty.

\section{RESUMO}

$\mathrm{O}$ objetivo deste estudo foi determinar a capacidade da prostaglandina $\mathrm{E}_{2}\left(\mathrm{PGE}_{2}\right)$ em induzir a ovulação e expressão do receptor $\mathrm{PGE}_{2}$ (EP2 e EP4) e genes COX (COX-1 e COX-2) no ovário e na hipófise de camundongos pré-púberes. O controle positivo consistiu na aplicação de $5 \mu$ g de hormônio liberador de gonadotrofina ( $\mathrm{GnRH}, \mathrm{n}=29)$; o controle negativo aplicação $0,5 \mathrm{~mL}$ de tampão fosfato-salino (PBS, $\mathrm{n}=31$ ); o tratamento testado aplicação de $250 \mu \mathrm{g}$ de PGE2 $(\mathrm{n}=29)$, perfazendo um total de 89 camundongos (BALB/c) pré-púberes. Os camundongos foram sacrificados 14 a $15 \mathrm{~h}$ após os tratamentos para detectar ovulações e coleta de tecido. O teste do qui-quadrado foi usado para comparar a proporção de animais ovulando. As expressões gênicas e o número de ovulação foram analisados por ANOVA e o teste de tukey foi usado para comparar as médias entre os grupos. Uma maior proporção de camundongos $(\mathrm{P}<0,001)$ ovulou após receber $\operatorname{GnRH}(89,7 \%, 26 / 29)$ em comparação com o grupo $\mathrm{PGE}_{2}(58,6 \%, 17 / 29)$. No entanto, a proporção foi maior em comparação com aqueles tratados com PBS (0\%, 0/31). A expressão do gene Ep2 na hipófise foi duas vezes maior $(\mathrm{P}<0,05)$ no grupo $\mathrm{PGE}_{2}$ em comparação com os grupos $\mathrm{PBS}$ e $\mathrm{GnRH}$. Além disso, a $\mathrm{PGE}_{2}$ estimulou a Cox1 (2,7 vezes, $\mathrm{P}<0,05)$ enquanto o $\mathrm{GnRH}$ estimulou a expressão de Cox2 (6,5 vezes, $\mathrm{P}<0,05)$ na pituitária em comparação com o grupo PBS. Em conclusão, nossos resultados suportam a hipótese de que $\mathrm{PGE}_{2}$ é capaz de induzir ovulação em camundongos pré-púberes com aumento concomitante na expressão dos genes Ep2 e Cox1 na glândula pituitária.

Palavras-chave: Ovulação. Prostaglandina. Receptor. Puberdade. 


\section{Correspondence to:}

Luiz Francisco Machado Pfeifer

Embrapa Rondônia

BR 364, Km 5,5, Zona Rural, Caixa Postal 127

CEP: 76815-800, Porto Velho, RO - Brazil

e-mail: luiz.pfeifer@embrapa.br

Received: March 3, 2021

Approved: July 29, 2021

How to cite: Andrade JS, Zuliani JP, Singh J, Setúbal SS, Silva RR, Schneider A, Pfeifer LFM. Prostaglandin E2 induces ovulation in prepubertal mice. Braz J Vet Res Anim Sci. 2021;58:e182745. https://doi.org/10.11606/ issn.1678-4456.bjvras.2021.182745

The identification and study of new molecules to induce ovulation could help introduce important alternatives to increase the use of reproductive biotechniques and, consequently, enhance the productivity in domestic mammals of economic interest. In that regard, before testing alternatives directly in such animals with expensive experiments, it is necessary to study the effect of ovulation inducer in laboratory species. In this context, here we evaluated the effect of $\mathrm{PGE}_{2}$ on the ovulation of mice. Although the effect of endogenous secretion of $\mathrm{PGE}_{2}$ in the ovary is well documented (Ben-Ami et al., 2006; Clasadonte et al., 2011; Espey, 1978; Li et al., 2006; Martínez-Boví \& Cuervo-Arango, 2016; Murdoch et al., 1993; Niringiyumukiza et al., 2018; Ojeda \& Negro-Vilar, 1985; Saksena et al., 1974; Segi et al., 2003; Sirois \& Richards, 1992; Sirois et al., 1992), limited information is available regarding the effect of injectable $\mathrm{PGE}_{2}$ on ovulation in juvenile females. Therefore, the primary objective of this study was to evaluate the effect of $\mathrm{PGE}_{2}$ administration on ovulation in prepubertal mice. The study of the expression of COX and prostaglandin EP receptor genes in the pituitary and ovary may provide an important step towards the understanding of its mechanism of action and the events that control reproduction. We tested the hypothesis that the administration of $\mathrm{PGE}_{2}$ will induce ovulation and alter the expression pattern of COX-1, COX-2, EP2, and EP4 genes in the pituitary and the ovary in prepubertal mice.

The Committee for Ethics in Animal Experimentation from the Oswaldo Cruz Foundation in Rondônia (Fiocruz-Rondônia) approved all procedures performed in the experiment described in this manuscript (Protocol 2014/12). Prepubertal female BALB/c $(n=89)$, between 18 and 22 days of age and weighing 20-25g, had access to food and water ad libitum.
To induce follicle growth, prepubertal mice were treated with an intraperitoneal (i.p.) dose of $0.2 \mathrm{UI}$ eCG per g body weight (equine chorionic gonadotrophin (Novormon', ZoetisPfizer, Brazil); total dose of 5 IU per mice) at the end of the light cycle. After 48 to $50 \mathrm{~h}$, mice were randomly assigned to one of the 3 experimental groups, and given a single i.p dose of 1) $20 \mu \mathrm{L}$ PBS per g body weight (Dulbecco-modified phosphate-buffered saline; Biodux;, Brazil; total dose of $0.5 \mathrm{~mL}$ per mice; $\mathrm{n}=31$, placebo control, $\mathrm{PBS}$ group); 2 ) $0.2 \mu \mathrm{g} \mathrm{GnRH}$ per g body weight (gonadotrophin-releasing hormone, Gonaxal ${ }^{\oplus}$, Biogenesis-Bagó, Argentina; total dose of $5 \mu \mathrm{g}$ per mice, $\mathrm{n}=29$; positive control, GnRH group), or 3) $10 \mu \mathrm{gGE}_{2}$ per g body weight (Sigma-Aldrich, USA; total dose of $250 \mu \mathrm{g}$ per animal, $\mathrm{n}=29$; PGE group). Mice were euthanized by cervical dislocation 14 to $15 \mathrm{~h}$ after the administration of treatments according to Bogle et al. (2011). The oviducts, ovaries, and pituitary were collected. The ovaries and pituitary were then placed in a $1.5 \mathrm{~mL}$ cryotube filled with $1 \mathrm{~mL}$ of RNALater (Sigma-Aldrich, USA). The cumulus-oocyte complexes (COCs) were detected in the oviduct ampullae under a stereomicroscope.

Total RNA was extracted from the pituitary and ovaries of a subset of mice ( $\mathrm{n}=4$ each group) selected at random before euthanasia. After complete removal of the RNALater from the samples, the tissues were macerated mechanically under liquid nitrogen and $600 \mu \mathrm{L}$ of $1 \% \beta$-mercaptoethanol (Sigma-Aldrich, USA) was added before total RNA was extracted according to the PureLink RNA Mini kit (Carlsbad, CA, USA) protocol. cDNA synthesis and quantitative real-time-PCR (qRT-PCR) were performed according to Pfeifer et al. (2018). Primers used to evaluate the qRT- PCR is described in Table 1.

Statistical analyses were performed using SAS 9.0 statistical program (Statistical Analysis System Institute, Inc., Cary, NC, USA, 2004). The proportion of female mice that ovulated was analyzed using the Chi-square test. The mean number of COC collected per animal and the gene expression was analyzed by one-way ANOVA and Tukey's test was used to compare the means among groups. A P-value equal to or less than 0.05 was considered statistically significant.

No mice ovulated in the control group, while a greater proportion of mice ovulated in the $\mathrm{PGE}_{2}$ group $(\mathrm{P}<0.001$; Table 2). Furthermore, the number of ovulations per mouse was higher in $\mathrm{PGE}_{2}$ treated mice than the $\mathrm{PBS}$ treated ones $(\mathrm{P}<0.001)$. The results of this study supported the primary hypothesis that treatment with $\mathrm{PGE}_{2}$ induces ovulation in prepubertal mice. Although previous studies have demonstrated the involvement of $\mathrm{PGE}_{2}$ in the ovulatory events of mammals (Li et al., 2006; Martínez-Boví \& Cuervo- 
Table 1 - Primer designed and used in the quantitative real-time polymerase chain reaction (qRT-PCR) amplification of mRNA

\begin{tabular}{|c|c|c|}
\hline Gene & Primer direction & Primer sequence $\left(5^{\prime}-3^{\prime}\right)$ \\
\hline \multirow[t]{2}{*}{ Gapdh } & forward & ACACTGAGGACCAGGTTG \\
\hline & reverse & TGGTCGTTGAGGGCAATG \\
\hline \multirow[t]{2}{*}{ ßactin } & forward & AGGCATCCTGACCCTCAAGTA \\
\hline & reverse & GCTCGTTGTAGAAGGTGTGGT \\
\hline \multirow[t]{2}{*}{ Cox 1} & forward & TGCATGTGGCTGTGGATGTCATCAA \\
\hline & reverse & CACTAAGACAGACCCGTCATCTCCA \\
\hline \multirow[t]{2}{*}{$\operatorname{Cox} 2$} & forward & GAGTGGGGTGATGAGCAACTATTCC \\
\hline & reverse & CTGTAGGGTTAATGTCATCTAGTCT \\
\hline \multirow[t]{2}{*}{ Ep2 } & forward & GCTCCTTGCCTTTCACAATCTT \\
\hline & reverse & CAGGACCGGTGGCCTAAGTA \\
\hline \multirow[t]{2}{*}{ Ep4 } & forward & GCACTGCGTGGGAAGAGACT \\
\hline & reverse & ATGGTACCTGTAGGGTGGGG \\
\hline
\end{tabular}

Table 2 - Proportion of prepubertal mice that ovulated and mean \pm S.E.M. of the number of ovulations per mice treated intraperitoneally with $0.5 \mathrm{ml}$ PBS, $5 \mu \mathrm{g}$ GnRH and $250 \mu \mathrm{g}$ PGE $_{2}$ (Porto Velho, 2021)

\begin{tabular}{|c|c|c|c|c|}
\hline \multirow{2}{*}{ Ovarian response } & \multicolumn{4}{|c|}{ Treatments } \\
\hline & $0.5 \mathrm{~mL}$ PBS & $5 \mu \mathrm{g} \mathrm{GnRH}$ & $250 \mu \mathrm{g} \mathrm{PGE}$ & P-Value \\
\hline Proportion of mice that ovulated (\%) & $0 / 31(0.0 \%)^{A}$ & $26 / 29(89.7 \%)^{B}$ & $17 / 29(58.6 \%)^{C}$ & $<0.001$ \\
\hline Number of ovulations per ovulating mice & $0.0 \pm 0.0^{A}$ & $7.1 \pm 0.9^{\mathrm{B}}$ & $3.3 \pm 0.7^{c}$ & $<0.001$ \\
\hline
\end{tabular}

PBS, phosphate-buffered saline; GnRH, gonadotropin-releasing hormone; $\mathrm{PGE}_{2}$, prostaglandin $\mathrm{E}_{2}$. ${ }^{\mathrm{ABC}}$ Within rows, values with no common superscript are different $(\mathrm{P}<0.05)$.

Arango, 2016; Murdoch et al., 1993; Saksena et al., 1974; Tsafriri et al., 1972), to the best of our knowledge, this is the first report to determine that $\mathrm{PGE}_{2}$ per se can induce ovulation in prepubertal mice. A greater proportion of mice ovulated after treatment with $\mathrm{GnRH}$ compared to those treated with PBS or $\mathrm{PGE}_{2}(\mathrm{P}<0.001)$. The number of ovulations per mouse was also higher in the $\mathrm{GnRH}$ group compared to $\mathrm{PGE}_{2}$ and $\mathrm{PBS}$ groups $(\mathrm{P}<0.001$; Table 2$)$. The relative abundance of Cox 1, Cox 2, Ep2, and Ep4 mRNA is depicted in Figure 1. There was no difference $(\mathrm{P}>0.05)$ in ct values of $\beta$ actin and Gapdh among groups for the ovarian tissue and pituitary gland.

The relative expression of Cox 1 in the ovary was higher $(\mathrm{P}<0.001)$ for GnRH treated mice compared to PBS and $\mathrm{PGE}_{2}$. Cox 2 expression was higher $(\mathrm{P}<0.05)$ in mice treated with GnRH compared to $\mathrm{PBS}$, while $\mathrm{PGE}_{2}$ group expression was intermediate. The GnRH and $\mathrm{PGE}_{2}$ treatments did not affect the expression of Ep2 and Ep4 in the ovary $(\mathrm{P}>0.05)$. Prostaglandin $\mathrm{E}_{2}$ treatment did not alter Ep2, Ep4, Cox1, or Cox 2 mRNA levels in the ovaries. However, whether the $\mathrm{PGE}_{2}$-induced ovulations result from the local ovarian effect, direct effect on the pituitary, through modulation of GnRH at the hypothalamic levels, or some combination of these mechanisms remains to be explored further.

Although the main objective of this study was to evaluate the effect of $\mathrm{PGE}_{2}$ on ovulation in prepubertal mice, we also attempted to elucidate the pattern of mRNA transcripts for PGE receptors and COX enzymes involved in cell receptivity and synthesis, respectively, in tissues where prostaglandins may act, such as the ovary (Espey, 1978; Evans et al., 1983; Fortune et al., 2009; Martínez-Boví \& Cuervo-Arango, 2016) and the pituitary (Clasadonte et al., 2011; Myren et al., 2012; Naor et al., 2007; Randel et al., 1996). In the pituitary gland, the Cox 1 and Ep2 expression was 2.7 (range: 1.5 to 3.9 ) and 2.0-fold (range: 1.5 to 2.7 ) higher ( $\mathrm{P}<0.05$; respectively) for mice treated with $\mathrm{PGE}_{2}$ compared to $\mathrm{PBS}$. In addition, mice treated with $\mathrm{PGE}_{2}$ had a higher relative expression of $E p 2$ than the $\mathrm{GnRH}$ group $(P<0.05)$. The relative expression of Cox2 was higher $(\mathrm{P}<0.05)$ in mice treated with $\mathrm{GnRH}$ compared to $\mathrm{PBS}$, while the $\mathrm{PGE}_{2}$ group was not different from either GnRH or PBS. The GnRH and $\mathrm{PGE}_{2}$ treatments did not change the expression of Ep4 receptors in the pituitary $(\mathrm{P}>0.05)$.

In the present study, $\mathrm{PGE}_{2}$ induced ovulation in $58 \%$ of the prepubertal eCG-stimulated mice within 14 to $15 \mathrm{~h}$ compared to almost $90 \%$ mice after GnRH treatment. Furthermore, the number of ovulations per mouse was less than half in comparison to $\mathrm{GnRH}$ (3.3 versus 7.1). The higher relative amounts of mRNA transcripts for Ep2 and Cox 1 detected in the pituitary of $\mathrm{PGE}_{2}$ treated mice corroborates this statement. Compared to the control and GnRH treatment, $\mathrm{PGE}_{2}$ treatment upregulated the Ep2 gene expression in 




\section{Pituitary}
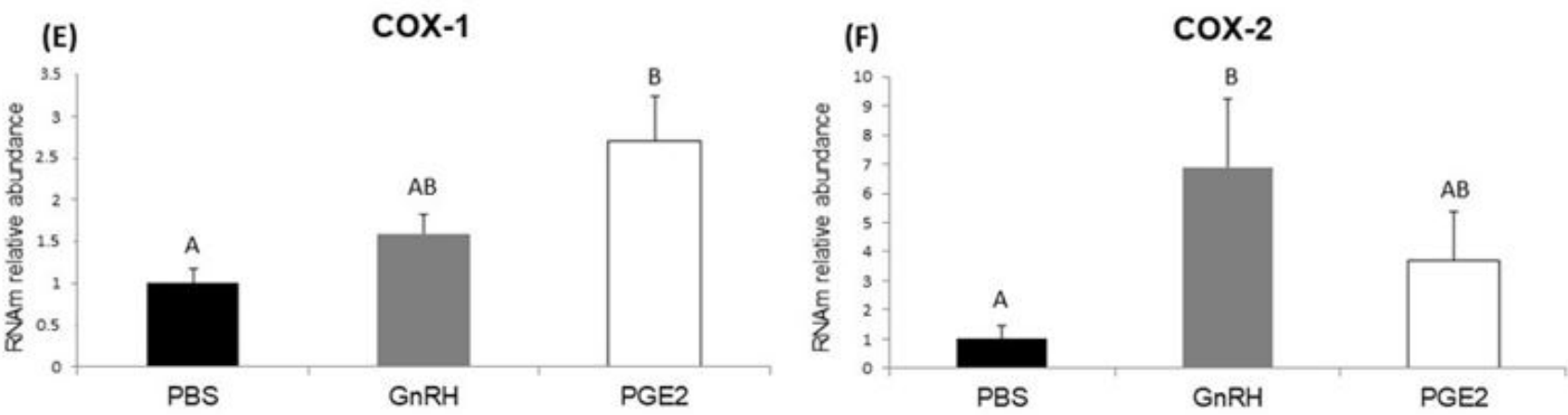

(G)

EP2

(H)

EP4
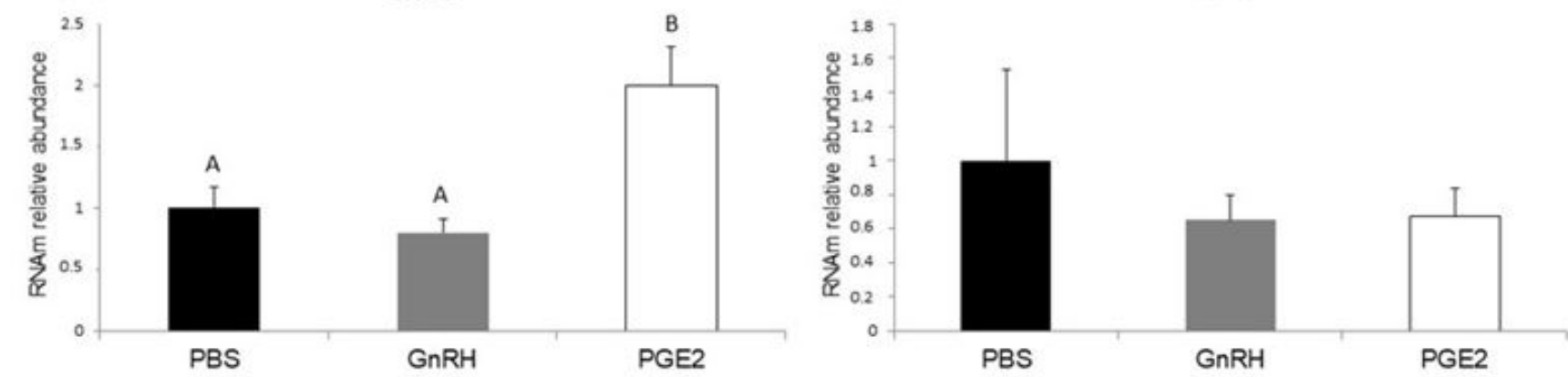

Figure 1 - Relative mRNA transcript abundance in the ovary (A-D) and the pituitary $(E-H)$ in prepubertal female mice $(n=4$ per group) induced to ovulate with PBS, GnRH, or PGE2. Different letters indicate differences among groups $(\mathrm{P}<0.05)$. Relative abundance was normalized based on the $\beta$ actin and Gapdh expression.

the pituitary. $\mathrm{PGE}_{2}$ differentially stimulated the Cox 1 while GnRH enhanced Cox2 expression in the pituitary.

In conclusion, our results support the hypothesis that $\mathrm{PGE}_{2}$ can induce ovulation in prepubertal mice with a concomitant increase in Ep2 and Cox 1 gene expression in the pituitary gland at $14-15 \mathrm{~h}$ after treatment. Further studies are needed to elucidate the local versus the central role of prostaglandins in follicle rupture and to verify the proposed mechanisms of action. 


\section{Conflict of Interest}

The authors declare no conflicts of interest.

\section{Ethics Statement}

The Committee for Ethics in Animal Experimentation from the Oswaldo Cruz Foundation in Rondônia (FiocruzRondônia) approved all procedures performed in this experiment (Protocol 2014/12).

\section{References}

Ben-Ami I, Freimann S, Armon L, Dantes A, Strassburger D, Friedler S, Raziel A, Seger R, Ron-El R, Amsterdam A. PGE2 up-regulates EGF-like growth factor biosynthesis in human granulosa cells: new insights into the coordination between PGE2 and LH in ovulation. Mol Hum Reprod. 2006;12(10):593-9. http://dx.doi.org/10.1093/molehr/ gal068. PMid:16888076.

Bogle OA, Ratto MH, Adams GP. Evidence for the conservation of biological activity of ovulation-inducing factor in seminal plasma. Reproduction. 2011;142(2):277-83. http://dx.doi. org/10.1530/REP-11-0042. PMid:21652637.

Clasadonte J, Poulain P, Hanchate NK, Corfas G, Ojeda SR, Prevot V. Prostaglandin E 2 release from astrocytes triggers gonadotropin-releasing hormone $(\mathrm{GnRH})$ neuron firing via EP2 receptor activation. Proc Natl Acad Sci USA. 2011;108(38):16104-9. http://dx.doi.org/10.1073/ pnas.1107533108. PMid:21896757.

Espey LL. Ovarian contractility and its relationship to ovulation: a review. Biol Reprod. 1978;19(3):540-51. http:// dx.doi.org/10.1095/biolreprod19.3.540. PMid:31208.

Evans G, Dobias M, King GJ, Armstrong DT. Production of prostaglandins by porcine preovulatory follicular tissues and their roles in intrafollicular function. Biol Reprod. 1983;28(2):322-8. http://dx.doi.org/10.1095/ biolreprod28.2.322. PMid:6404317.

Fortune JE, Willis EL, Bridges PJ, Yang CS. The periovulatory period in cattle: progesterone, prostaglandins, oxytocin and ADAMTS proteases. Anim Reprod. 2009;6(1):60-71. PMid:20390049.

Li Q, Jimenez-Krassel F, Kobayashi Y, Ireland JJ, Smith GW. Effect of intrafollicular indomethacin injection on gonadotropin surge-induced expression of select extracellular matrix degrading enzymes and their inhibitors in bovine

\section{Acknowledgements}

The authors express their gratitude to the National Council for Scientific and Technological Development (CNPq; 482562/2010-2 and 479316-2013-6), Coordination for the Improvement of Higher Education Personnel (CAPES), and the Rondônia (FAPERO) for the financial support. We sincerely thank all the members of the Labiotec laboratory who assisted in the preparation of this study.

preovulatory follicles. Reproduction. 2006;131(3):533-43. http://dx.doi.org/10.1530/rep.1.00926. PMid:16514196.

Martínez-Boví R, Cuervo-Arango J. Follicle diameter and systemic hormone interrelationships during induction of follicle collapse with intrafollicular prostaglandin E2 and F2 $\alpha$ in Mares. Reprod Domest Anim. 2016;51(2):322-9. http://dx.doi.org/10.1111/rda.12683. PMid:26931199.

Murdoch WJ, Hansen TR, McPherson LA. A review - Role of eicosanoids in vertebrate ovulation. Prostaglandins. 1993;46(8):85-115. http://dx.doi.org/10.1016/00906980(93)90037-8. PMid:8210447.

Myren M, Olesen J, Gupta S. Prostaglandin E 2 receptor expression in the rat trigeminal-vascular system and other brain structures involved in pain. Neurosci Lett. 2012;506(1):64-9. http://dx.doi.org/10.1016/j.neulet.2011.10.050. PMid:22061836.

Naor Z, Jabbour HN, Naidich M, Pawson AJ, Morgan K, Battersby S, Millar MR, Brown P, Millar RP. Reciprocal cross talk between gonadotropin-releasing hormone $(\mathrm{GnRH})$ and prostaglandin receptors regulates $\mathrm{GnRH}$ receptor expression and differential gonadotropin secretion. Mol Endocrinol. 2007;21(2):524-37. http://dx.doi.org/10.1210/ me.2006-0253. PMid:17138645.

Niringiyumukiza JD, Cai H, Xiang W. Prostaglandin E2 involvement in mammalian female fertility: ovulation, fertilization, embryo development and early implantation. Reprod Biol Endocrinol. 2018;16(1):43. http://dx.doi. org/10.1186/s12958-018-0359-5. PMid:29716588.

Ojeda SR, Negro-Vilar A. Prostaglandin E2-induced luteinizing hormone-releasing hormone release involves mobilization of intracellular Ca+2. Endocrinology. 1985;116(5):1763-70. http://dx.doi.org/10.1210/endo-116-5-1763. PMid:2985358. 
Pfeifer LFM, de Souza Andrade J, Moreira EM, Reis da Silva R, Araújo Neves PM, Moreira da Silva G, Lemos IC, Schneider A. Uterine inflammation and fertility of beef cows subjected to timed AI at different days postpartum. Anim Reprod Sci. 2018;197:268-77. http://dx.doi.org/10.1016/j. anireprosci.2018.08.039. PMid:30195943.

Randel RD, Lammoglia MA, Lewis AW, Neuendorff DA, Guthrie MJ. Exogenous PGF2 $\alpha$ enhanced GnRH-induced LH release in postpartum cows. Theriogenology. 1996;45(3):64354. http://dx.doi.org/10.1016/0093-691X(95)00410-A. PMid:16727826.

Saksena SK, Lau IF, Shaikh AA. Cyclic changes in the uterine tissue content of F-prostaglandins and the role of prostaglandins in ovulation in mice. Fertil Steril. 1974;25(7):636-43. http:// dx.doi.org/10.1016/S0015-0282(16)40521-2. PMid:4858379.

Segi E, Haraguchi K, Sugimoto Y, Tsuji M, Tsunekawa H, Tamba S, Tsuboi K, Tanaka S, Ichikawa A. Expression of messenger RNA for prostaglandin E receptor subtypes EP4/EP2 and cyclooxygenase isozymes in mouse periovulatory follicles and oviducts during superovulation. Biol Reprod. 2003;68(3):804-11. http://dx.doi.org/10.1095/ biolreprod.102.003590. PMid:12604629.
Sirois J, Richards JS. Purification and characterization of a novel, distinct isoform of prostaglandin endoperoxide synthase induced by human chorionic gonadotropin in granulosa cells of rat preovulatory follicles. J Biol Chem. 1992;267(9):6382-8. http://dx.doi.org/10.1016/S00219258(18)42706-8. PMid:1556140.

Sirois J, Simmons DL, Richards JS. Hormonal regulation of messenger ribonucleic acid encoding a novel isoform of prostaglandin endoperoxide $\mathrm{H}$ synthase in rat preovulatory follicles. Induction in vivo and in vitro. J Biol Chem. 1992;267(16):11586-92. http://dx.doi.org/10.1016/S00219258(19)49951-1. PMid:1597485.

Tsafriri A, Lindner HR, Zor U, Lamprecht SA. Physiological role of prostaglandins in the induction of ovulation. Prostaglandins. 1972;2(1):1-10. http://dx.doi.org/10.1016/00906980(72)90024-X. PMid:4579171.

Financial Support: The authors express their gratitude to the National Council for Scientific and Technological Development (CNPq; 482562/2010-2 and 479316-2013-6), Coordination for the Improvement of Higher Education Personnel (CAPES), and the Rondônia (FAPERO) for the financial support. 